\title{
Leprosy in Preschool Age
}

\author{
C. R. REVANKAR*, P. R. DEWARKER†, SINGH MULCHAND** \& R. \\ GANAPATI*.
}

\begin{abstract}
* Acworth Leprosy Hospital Society for Research, Rehabilitation and Education in Leprosy, Wadala, Bombay-400031, India and Bombay Leprosy Project, 6/27, Amar Bhuvan, Sion (East), Bombay-400 022, India

** Vimala Dermatological Centre, Versova, Bombay-400 061, India

† Bombay Leprosy Project, 6/27, Amar Bhuvan, Sion (East), Bombay-400 022, India
\end{abstract}

\begin{abstract}
Examination of 4235 preschool age (1-5 years) children from various slums in Bombay revealed 20 active leprosy cases (prevalence rate of 4.7 per 1000). An analysis of pooled figures from clinics showed that preschool children formed $1.3 \%$ of the total number of patients attending these clinics. $5 \%$ were smear positive; $45 \%$ had one or more family members with leprosy $(25 \%$ of the latter being bacteriologically positive). The high proportion of associated infectious cases (as compared to corresponding data for school age) indicates a strong possibility of intrafamilial infection in children of preschool age.
\end{abstract}

\section{Introduction}

The focus of attention all over the world in this "International Year of the Child" on problems related to children prompted us to study the literature from the point of view of childhood leprosy. Though there have been several publications recently (Kurian et al., 1975; Ganapati et al., 1976; Noussitou et al., 1976; Koticha 1976) on leprosy in school-going children, we did not find any large data on the prevalence of leprosy in preschool age, (1-5 years). Bechelli et al. (1966) found varying prevalence rates ranging from 1.5 (Cameroon) to 2.1 (N. Nigeria) for the population in the age group 1-4 years.

We have therefore analysed relevant figures obtained from surveys from two urban field projects as well as those from clinics where patients reported voluntarily.

\section{Observations}

\section{(a) DATA FROM THE FIELD}

The field data were collected from groups of slums situated in the northern suburbs of the city of Bombay in which 2 voluntary agencies namely the Bombay Leprosy Project and Vimala Dermatological Centre are active. 
A population of 37,399 was enumerated of which 4403 (12\%) were in the preschool age group (1-5 years).

TABLE 1

Prevalence rates in various age groups

\begin{tabular}{|c|c|c|c|c|}
\hline Population & Enumeration & Examination & Leprosy cases & $\begin{array}{l}\text { Prevalence } \\
\text { rate } / 1000\end{array}$ \\
\hline $\begin{array}{l}\text { Preschool } \\
\quad \text { (1-5 years) }\end{array}$ & $\begin{array}{r}4403 \\
(12 \%)\end{array}$ & $\begin{array}{r}4235 \\
(96 \%)\end{array}$ & 20 & 4.7 \\
\hline $\begin{array}{l}\text { School } \\
\quad(5-14 \text { years })\end{array}$ & $\begin{array}{r}9441 \\
(25 \%)\end{array}$ & $\begin{array}{r}8416 \\
(89 \%)\end{array}$ & 127 & 15.0 \\
\hline $\begin{array}{l}\text { Above } \\
14 \text { years }\end{array}$ & $\begin{array}{l}23,495 \\
(63 \%)\end{array}$ & $\begin{array}{l}17,276 \\
(74 \%)\end{array}$ & 426 & 24.7 \\
\hline ГО'ГАL: & $\begin{array}{l}37,339 \\
(100 \%)\end{array}$ & $\begin{array}{l}29,927 \\
(80 \%)\end{array}$ & 573 & 19.0 \\
\hline
\end{tabular}

1. Twenty preschool children were found to be suffering from active leprosy (Prevalence rate of 4.7 per 1000); the overall prevalence rate in the total population was 19 per 1000 .

2. The preschool leprosy cases formed $3.5 \%$ of the total of 573 leprosy cases and $13.6 \%$ of the total $147(20+127)$ childhood cases (between 1 to 14 years).

3. Of the 20 children 13 were female (Male to female ratio was $1: 2$ ).

4. Two (10\%) had the N? $\mathrm{L}^{*}$ type of disease (BT-BB-according to RidleyJopling classification); the remaining $18(90 \%)$ were of $\mathrm{N}^{*}$ type.

5. No smear positive case was found.

(b) DATA FROM THE CLINICS (POOLED FIGURES)

An analysis of pooled data from the records from various central and peripheral treatment centres in Bombay revealed 511 leprosy cases in the preschool group and these (including 20 cases described above) formed $1.3 \%$ of 38,478 leprosy patients attending these clinics.

As many household contacts of the 511 children with leprosy as were available were examined in the clinics. The results are tabulated below, and compared with corresponding data for school age children from a previous study.

1. Familial association of leprosy in the preschool and school age group was $45 \%$ and $14 \%$ respectively.

2. $126(25 \%)$ of the preschool cases had a bacteriologically positive (potentially infectious) case in the family. In the school group study on the other hand only $1 \%$ of the associated family cases were infectious.

* See footnote to Table 2. 
TABLE 2

Clinical features of the preschool cases from the clinics

\begin{tabular}{lccccc}
\hline $\begin{array}{l}\text { Total } \\
\text { preschool } \\
\text { cases }\end{array}$ & $\mathrm{N}^{*}$ & $\mathrm{~N} ? \mathrm{~L}^{*}$ & $\mathrm{~L}^{*}$ & $\begin{array}{c}\text { Smear } \\
\text { positive } \\
\text { cases }\end{array}$ & $\begin{array}{c}\text { Polyneuritic } \\
\text { involvement }\end{array}$ \\
\hline 511 & $\begin{array}{c}407 \\
(79.6 \%)\end{array}$ & $\begin{array}{c}103 \\
(20.2 \%)\end{array}$ & $\begin{array}{c}1 \\
(0.2 \%)\end{array}$ & $\begin{array}{c}23 \\
(5 \%)\end{array}$ & $\begin{array}{c}3 \\
(0.6 \%)\end{array}$ \\
\hline
\end{tabular}

* Clinical typing (field classification)

$\mathrm{N}$, Nonlepromatous (Indeterminate and tuberculoid).

$\mathrm{N}$ ? L, Intermediate forms (Borderline-BT - BL according to Ridley-Jopling scale)

L, Lepromatous.

(Classified according to the Operational Guide and Guidelines of Assessment of leprosy work in India 1969).

$\mathrm{N}$ cases generally had only single lesions.

TABLE 3

Clinical types of associated cases in the families of the preschool cases

\begin{tabular}{lcccc}
\hline & \multicolumn{2}{c}{$\begin{array}{c}\text { No. of preschool } \\
\text { leprosy children }\end{array}$} & \multicolumn{2}{c}{ Clinical types } \\
Cases & $\begin{array}{c}\text { With associ- } \\
\text { ated cases }\end{array}$ & $\begin{array}{c}\text { With smear + ve } \\
\text { asso. cases }\end{array}$ & $\begin{array}{c}\text { Of index } \\
\text { cases }\end{array}$ & $\begin{array}{c}\text { Of asso. } \\
\text { cases }\end{array}$ \\
\hline Preschool & $232 / 511(45 \%)$ & $126 / 511(25 \%)$ & L-1 & L-85 \\
group (present & & & N?L-91 & N?L-125 \\
analysis) & & & N-140 & N-85 \\
School group & $27 / 190(14 \%)$ & $2 / 190(1 \%)$ & L-1 & L-2 \\
(Ganapati & & & N?L-2 & N?L-1 \\
et al., 1978) & & & N-24 & N-38 \\
\hline
\end{tabular}

\section{Discussion}

1. The field figures showed that the prevalence rate in preschool age is $1 / 3$ of that in the school group and $1 / 6$ of that found in the adult-group. It may be said that for every 1 preschool case, there were 3 school age cases and 6 adult cases in the community studied.

2. Advanced leprosy in preschool children was more likely to be seen at treatment clinics than in the field.

3. The high proportion of intra-familial case association for preschool children indicates a strong possibility of intraf amilial inf ection.

4. The importance of this study is that the presence of leprosy in preschool children indicates that the community is endemic for leprosy. 


\section{Acknowledgements}

We thank the Regional Secretary for India, German Leprosy Relief Association for permission to study the data from sponsored projects. We are grateful to the President, Acworth Leprosy Hospital Society for Research, Rehabilitation and Education in Leprosy, for financial support for the analysis.

\section{References}

Bechelli, L. M., Dominguez, V. M. and Patway, K. M. (1966). WHO Epidemiological random sample surveys of leprosy in Northern Nigeria (Katsina), Cameroon and Thailand (Khonkaen). Int. J. Lepr. 34, 223.

Ganapati, R., Naik, S. S., Acharekar, M. Y. and Pandya, S. S. (1976). Leprosy endemicity in Bombay: An assessment through surveys of municipal schools. Lepr. Rev. 47, 127.

Ganapati, R., Revankar, C. R., Christina and Romano (1978). Associated Cases in the Families of school children with leprosy. Lepr. Rev. 49, 43.

Koticha, K. K. (1976). Case detection through school surveys in Greater Bombay. Lepr. India 48, 819.

Kurian, P. V., Vasundhara V. and Devanbu, D. (1975). School survey as an effective method for leprosy control in rural areas. Lepr. India 37, 45.

Noussitou, F. M., Sansarricq, H. and Waeter, J. (1976). Leprosy in children, pp. 1-18. WHO Publication.

Operational Guide and Guidelines of Assessment of Leprosy Control work in India. (1969). Govt. of India Publication, p. 61. 